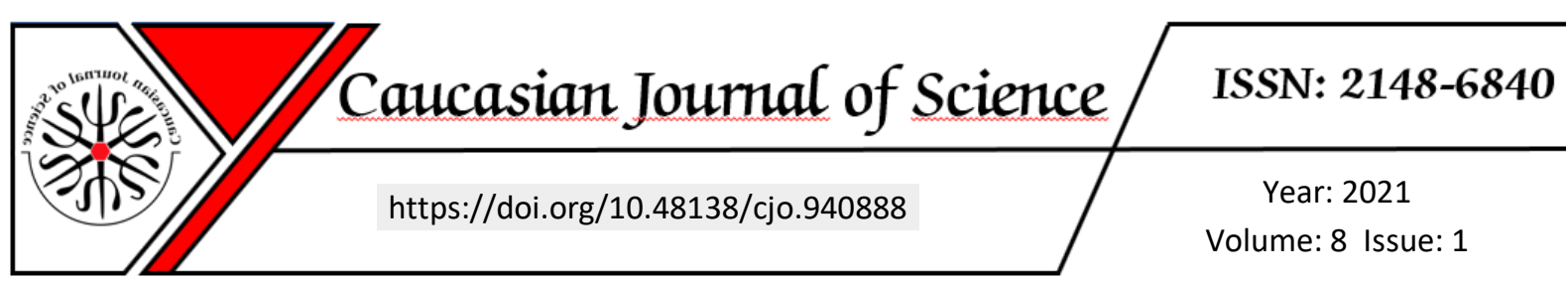

\title{
Gebelik Dermatozları ve Hemşirelik Bakımı
}

\author{
Özlem KARABULUTLU ${ }^{1}$, Cuma DEMIR ${ }^{2}$
}

Makalenin Alanı: Sağlık

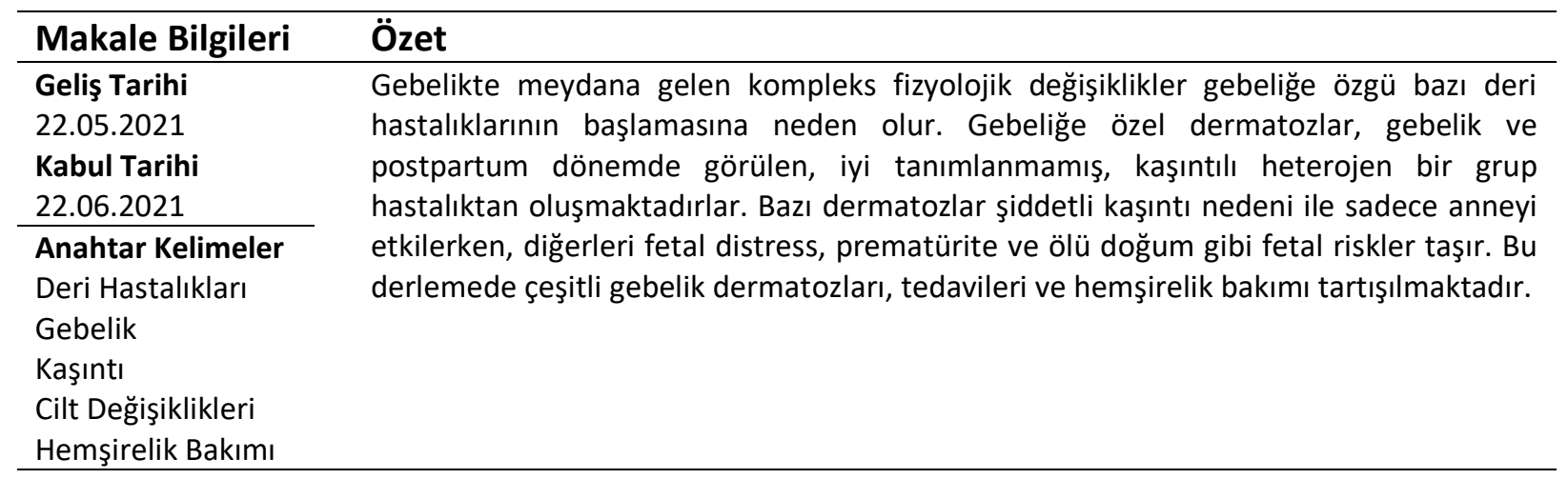

\begin{tabular}{ll}
\hline Article Info & Abstract \\
\hline Received & The complex physiologic changes occuring in pregnancy due to start some specific skin \\
22.05 .2021 & disorders of pregnancy. The specific dermatoses of pregnancy are composed of pruritic, \\
Accepted & heterogenous group of diseases that are not defined clearly and encountered only \\
22.06 .2021 & during pregnancy and postpartum period. Whereas some dermatoses are distressing \\
\hline Keywords & only to the mother because of severe pruritus, others are associated with fetal risks, \\
Dermatose & including fetal distress, prematurity and stillbirth. This review discusses the various \\
Pregnancy & pregnancy dermatoses, their management and nursing care. \\
Pruritus & \\
Skin Changes & \\
Nursing Care & \\
\hline
\end{tabular}

\section{GíRiş}

Gebelik, hormonal, immünolojik ve psikolojik değişiklikleriyle insan hayatındaki en özel dönemlerden biridir. Bu özel dönemde gebe kadınların ciltlerinde fizyolojik ve patolojik birtakım süreçler başlar. Bu değişiklikler anne adaylarında ciddi anksiyeteye yol açabilir. Cilt hastalıklarının çoğu gebe ve gebe olmayan kadınlarda eşit sıklıkta izlenir. Fakat gebeliğin neden olduğu hormonal değişiklikler deride belirgin etkiler yapabilir. Bu nedenle gebeliğe özgü ve semptomatik olan dermatozlar da vardır (Bitirgen ve ark., 2016).

\footnotetext{
${ }^{1}$ Kafkas University, Faculty of Health Sciences Department of Midwifery-Kars; e-mail: okarabulutlu@gmail.com; ORCID: 0000-0001-5307-5186 (Sorumlu Yazar)

${ }^{2}$ Kafkas University, Institute of Health Sciences-Kars; e-mail: cumademirmehmetakif@gmail.com; ORCID: 0000-0003-3361-8547
} 
Gebelikte görülen cilt hastalıkları üç kategoride izlenir (Bitirgen ve ark., 2016).

1-Hormonal cilt değişiklikleri

2-Daha önceden var olan deri hastalıkları

3-Gebeliğe spesifik hastalıklar (Gebelik dermatozları).

1-Gebelikteki hormonal değişiklikler; Hemen hemen her gebede görülebilecek olan "Olağan veya Fizyolojik" deri değişiklikleridir. Stria gravidarum, hiperpigmentasyon, saç ve tırnak değişiklikleri ve vasküler değişiklikler gibi benign durumları içerir (Bitirgen ve ark., 2016).

2-Daha önceden var olan cilt hastalıkları; Gebelikten önce var olan cilt hastalıkları bazı değişiklik gösterir. Çoğu cilt hastalıkları gebeliğin sonlanması ile gerilerken bazı durumlar tedavi gerektirir (Bitirgen ve ark., 2016). Gebelikle birlikte alevlenen, seyri değişen hastalıklar vardır. Kandida enfeksiyonları, genital siğiller, bowenoid papulosis, trikomonas enfeksiyonları artabilir, alevlenme gösterebilir. Pemfigus vulgaris gebelikte şiddetlenebilir veya başlayabilir. Sistemik Lupus Eritematozus (SLE) ve eritema nodozum gebelikte daha sık ortaya çıkar.

3-Gebelik dermatozları; Yalnızca gebelik ve postpartum dönemde görülen, iyi tanımlanmış, heterojen bir grup hastalıktan oluşmaktadır. Gebelikte gözlenen dermatozların terminolojisi oldukça karmaşıktır ve aynı klinik hastalık için birçok farklı isim ile ifade edilmektedir (Kurien and Badri, 2020; Can Gürkan ve Toraman, 2013).

Gebeliğe özel dermatozlar, karışıklığı gidermek amacıyla ilk olarak 1983 yılında Holmes ve Black tarafından sınıflandırılmış ve dört cilt durumu yaygın olarak kabul görmüştür. Bu sınıflamada, Pemfigoid (Herpes) Gestasyones (PG), Gebeliğin Polimorfik Erüpsiyonu (GPE), Gebelik Prurigosu (Prurigo Gestasyones (GP) ve Gebeliğin Pruritik Folliküliti (GPF) gebeliğe özel dermatozlar olarak kabul edilmektedir (Holmes and Black, 1982; Holmes and Black, 1983). Shornick 1998'de gebelik dermatozlarını yeniden sınıflandırmıştır. Shornick, tarafından önerilen ikinci sınıflandırmada, PG, GPE ve GP'ye ek olarak gebeliğin intrahepatik kolestazını (GIK) ilk kez gebelik dermatozu sınıflamasına eklenmiştir (Shornick, 1998). Ambros-Rudolph ve ark. 2006 yılında İngiltere ve Avusturya'da iki üniversite hastanesine başvuran 505 kaşıntılı gebe hastayı değerlendirmiş ve olguların \%49,7'sinde gebelik egzaması (GE) tespit etmişlerdir (Ambros-Rudolph et al., 2006). Ayrıca, hastalarında GE, Prurigo gestasyones (GP) ve gebeliğin pruritik folikülitinin (GPF) önemli ölçüde örtüşme gösterdiğini ve atopik yatkınlık ile ilişkili olduklarını bildirmişlerdir. Bu nedenle üç tablonun "gebeliğin atopik erüpsiyonu" (GAE) adı altında toplanması gerektiğini vurgulamışlardır. Sonuç olarak, Ambros-Rudolph ve ark. gebelik 
dermatozlarını Pemfigoid gestasyones (PG), gebeliğin polimorfik erüpsiyonu (GPE), gebeliğin intrahapatik kolestazı (GIK) ve gebeliğin atopik erüpsiyonu (GAE) olarak yeniden sınıflandırmışlardır (Vora et al., 2014; Medenica et al., 2008; Sachdeva, 2008).

Chander ve arkadaşlarının 2011 yılında yaptığı çalışmada; 1430 gebe kadın taranmış ve 70 hastada (\%5) gebeliğe özgü dermatoz saptanmıştır. Gebeliğe özgü dermatoz saptanan 70 hastanın \%54,2'sinde GiK, \%38,5'inde GAE, \%7,1'inin GPE olduğu belirlenmiştir. PG'ye rastlanmamıştır (Chander et al., 2011).

\section{Gebeliğin Intrahepatik Kolestazı (GIK)}

Sinonimler: Pruritus gravidarum, Prurigo gravidarum, obstetrik kolestaz ve gebeliğin tekrarlayan/idiyopatik sarılığı olarak da bilinir. Gebeliğin intrahepatik kolestazı (GIK), genetik yatkınlığı olan kişilerde, gebeliğin geç döneminde ortaya çıkan şiddetli kaşıntı ile karakterize reversible kolestazdır. Fetüs için fetal distres, erken doğum ve ölü doğum en ciddi risklerdir (Parlak, 2007).

Epidemiyoloji: Sıklığı, coğrafik bakımdan dramatik farklılıklar göstermektedir. Avrupa'da insidansı \%0,1-2,4 gebelik arasında değişmektedir. En sık Şili'de (\%15) görülmektedir (Lammert et al., 2000; Ambros-Rudolph, 2006). Genel olarak insidans 1/10001/10000 olarak düşünülmektedir.

Risk faktörleri: Hepatit C, kolelitiazis, kolesistektomi, çoğul gebelik ve anne yaşının ileri olmasıdır (Mullally and Hansen, 2002).

Etyoloji ve Patofizyoloji: Etyoloji kesin olarak bilinmemekle birlikte multifaktoriyel olduğu düşünülmektedir. Safra asit salınımındaki defekte bağlı serum safra asitleri yükselir. Deride biriken safra tuzları annede şiddetli kaşıntıya yol açar. Annede ayrıca steatore nedeniyle nadiren K vitamini eksikliği görülebilir (Snarskaya et al., 2019; Ambros-Rudolph and Sticherling, 2017; Bitirgen ve ark., 2016; Can Gürkan ve Toraman, 2013; İnan Yüksel ve ark., 2011; Ambros-Rudolph, 2011; Polat ve Dönmez, 2008, Parlak, 2007). Gebeliğin 3. trimesterinde, çoğul gebelikte (östrojen seviyesi yüksek) daha sık görülmesi ve oral kontraseptif alımı ile tekrarlaması hastalık etyopatogenezinde hormonların rolü olduğu düşüncesini desteklemektedir (Shornick, 2008; Kroumpouzos, 2002; Germain et al., 2002).

Belirtileri: GiK, olguların \%80'inde 30. haftadan sonra ortaya çıkmaktadır. İntrahepatik gebelik kolestazı tipik olarak avuç içi ve ayak tabanlarında başlayabilen ancak hızla genelleşen ani şiddetli kaşıntı ile kendini gösterir. Kaşıntı genellikle geceleri artar. Hamilelik boyunca devam edebilir. Gebeliğin intrahepatik kolestazı, birincil deri lezyonları ile ilişkili değildir. Klinik 
özellikler hastalık süresi ile ilişkilidir. Kaşıntı başladığında cilt genellikle tamamen etkilenmez; daha sonra, kaşınmaya bağlı olarak ikincil deri lezyonları gelişir ve kaşıntı devam ederken hafif ekskoriyalardan şiddetli prurigo nodüllere kadar değişir. Deri lezyonları genellikle ekstremitelerin ekstansör yüzeylerini içerir, ancak aynı zamanda kalça ve karın gibi vücudun diğer bölgelerini de etkileyebilir. Eşlik eden ekstrahepatik kolestaza bağlı sarılık, hastaların yaklaşık \%10'unda, genellikle 2-4 hafta sonra ortaya çıkar ve en şiddetli ve uzun süreli nöbetleri, komplike eder. Bu hastalar, $\mathrm{K}$ vitamini dahil yağda çözünen vitaminlerin emilim bozukluğu ve olası kanama komplikasyonlarının yanı sıra kolelitiazis ile steatore geliştirme riski altındadır (Snarskaya et al., 2019; Ambros-Rudolph and Sticherling, 2017; Bitirgen ve ark., 2016; Can Gürkan ve Toraman, 2013; İnan Yüksel ve ark., 2011; Ambros-Rudolph, 2011; Polat ve Dönmez, 2008). GIK, gebelerde viral hepatitten sonra en çok sarılığa neden olan ikinci hastalıktır. GIK ile birlikte görülebilecek diğer bulgular koyu renkte idrar, açık renkli gaita, sağ üst kadranda ağrı, öksürük ve üriner enfeksiyondur (Shornick, 2003; Sherard and Atkinson, 2001).

Tanı testleri: Histopatoloji spesifik değildir; doğrudan ve dolaylı immünofloresan negatiftir. Gebelikte intrahepatik kolestaz teşhisi için en hassas gösterge, serum safra asidi seviyelerinin yükselmesidir, rutin karaciğer fonksiyon testleri (transaminazlar dahil) \%30'a kadar normal olabilir. Serum safra asitlerinde, özellikle kolik asitte yemek sonrasında artış GIK için sensitif belirteçtir. GIK ayırıcı tanısında viral hepatitler, hepatotoksik ilaçlara maruz kalma hikâyesi ve diğer kaşıntı nedenleri araştırılmalıdır (Parlak, 2007). Sağlıklı gebeliklerde, toplam serum safra asidi seviyeleri hamile olmayan kadınlara göre biraz daha yüksektir ve $11.0 \mu \mathrm{mol}$ / l'ye (normal aralık, $0 \sim 6 \mu \mathrm{mol}$ / I) kadar olan seviyeler, gebeliğin sonlarında normal olarak kabul edilir. Hiperbilirubinemi sadece $\% 10 ~ 20$ oranında görülür; bu gibi durumlarda kolelitiazisi dışlamak için karaciğerin ultrason muayenesi gerekli olabilir (Snarskaya et al., 2019; AmbrosRudolph and Sticherling, 2017; Bitirgen ve ark., 2016; İnan Yüksel ve ark., 2011; AmbrosRudolph, 2011; Polat ve Dönmez, 2008).

Prognozu: GIK'nın etiyolojisi tam olarak bilinmemekle beraber hormonal, genetik, çevresel, mekanik ve beslenmeyle ilişkili olduğu tahmin edilmektedir. Anne için prognoz genellikle iyidir. Doğumdan sonra kaşıntı günler ile haftalar içinde kendiliğinden kaybolur ancak sonraki gebelikler ve oral kontrasepsiyon ile tekrarlayabilir. Etyopatogenez tam olarak bilinmemekle birlikte, gebenin kan dolaşımından, safra asitlerini metabolize ve sekrete eden enterohepatik sistemde bozukluk sebebiyle, serum safra asit düzeylerinin yükselmesiyle bu 
hastalık tablosunun oluştuğu bilinmektedir. Sarılık ve $\mathrm{K}$ vitamini eksikliği durumlarında hem anne hem de çocukta doğum içi ve doğum sonu kanama riski artar. Bununla birlikte, bu hastalıktaki kilit husus, maternal kaşıntı değil, önemli ölçüde bozulmuş fetal prognozdur. Fetal riski önceden gösteren tek yardımcı bulgu mekonyumla kirlenmiş amnion sıvısıdır (Germain et al., 2002). Prematürite (\%19-60), intrauterin fetal distres (\%22-33) ve ölü doğum (\%1-2) oranları oldukça artmıştır (Lammert et al.,2000). Serum safra asit düzeyi 40 $\mu \mathrm{mol} / \mathrm{L}$ üzerinde bulunan gebelerde fetal komplikasyon oranının arttı̆̆ı bildirilmektedir. Fetüs kaybedilmeden birkaç gün öncesine kadar nonstres testler normal olabilir. Fetüs kaybı genellikle 37. haftadan sonra olmaktadır (Mullally and Hansen, 2002). Bu nedenle, hızlı tanı, spesifik tedavi ve yakın obstetrik izleme ile özellikle sonraki gebeliklerde beklenen nüks konusunda anne danışmanlığı önemlidir (Snarskaya et al., 2019; Ambros-Rudolph and Sticherling, 2017; Bitirgen ve ark., 2016; Can Gürkan ve Toraman, 2013; İnan Yüksel ve ark., 2011; Ambros-Rudolph, 2011; Polat ve Dönmez, 2008).

Tedavi: Tedavide amaç serum safra asit düzeyini kontrol altına alarak erken doğum eylemini önlemek ve anne-bebek sağlığını sürdürmektir. S-adenosil-L-metionin, deksametazon, Ursodeoxycholic acid ve kolestiramin tedavi yönetiminde kullanılabilir bununla birlikte Ursodeoksikolik asit (UDCA) sadece maternal kaşıntıyı azaltmakla kalmayıp aynı zamanda fetal prognozu iyileştirdiği gösterilen tek tedavidir. Çin tıbbında 5000 yıldan uzun süredir çeşitli karaciğer hastalıklarının tedavisinde başarıyla kullanılan ve günümüzde hepatobiliyer bozuklukların tedavisinde anahtar rol oynayan, doğal olarak oluşan, hidrofilik, toksik olmayan bir safra asididir. Gebelikte intrahepatik kolestazda $15 \mathrm{mg} / \mathrm{kg} /$ gün veya vücut ağırlığından bağımsız olarak $1 \mathrm{gr} /$ gün doz ya tek doz olarak ya da genellikle durdurulabilen doğuma kadar 2 3 doza bölünür. Ara sıra meydana gelen hafif ishal haricinde herhangi bir yan etkisi yoktur. Bununla birlikte, UDCA hamilelikte kullanım için lisanslı değildir ve bu nedenle özel hasta bilgileri gerektirir ("etiket dışı kullanım"). Diğer antihistaminikler, Sadenosil-L-metionin, deksametazon içeren ilaçlar ve kolestiramin fetal prognoz geliştirmek olabilir. Kolestiramin ve diğer safra asidi değişim reçineleri, olası ardışık kanama komplikasyonları ile $\mathrm{K}$ vitamininin emilim bozukluğuna katkıda bulunabilir ve bu nedenle kaçınılmalıdır. UDCA tedavisine ek olarak, yakın obstetrik gözetim endikedir ve en az 34 . gebelik haftasından itibaren haftalık fetal kardiyotokografik (CTG) kaydını içerir; Akciğer olgunluğuna ulaşılır ulaşılmaz erken doğum (36 37 hafta) bazı araştırmacılar tarafından önerilmektedir. Dermatologlar, hepatologlar, jinekologlar ve pediatristler tarafından gebelikte 
intrahepatik kolestazın disiplinlerarası bir yönetimi kesinlikle zorunludur (Snarskaya et al., 2019; Ambros-Rudolph and Sticherling, 2017; Bitirgen ve ark., 2016; Can Gürkan ve Toraman, 2013; İnan Yüksel ve ark., 2011; Ambros-Rudolph, 2011; Polat ve Dönmez, 2008).

\section{Pemphigoid Gestationis (Synonym: Herpes Gestationis) PG}

Tanım: PG nadir, otoimmün, veziko-büllöz şiddetli kaşıntı ile karakterize, genellikle gebeliğin sonlarında veya hemen doğum sonrası dönemde ortaya çıkan, ancak üç trimesterden herhangi birinde görülebilen, nadir görülen, kendi kendini sınırlayan, otoimmün büllöz bir hastalıktır. Hamileliğin ötesinde çok nadiren trofoblastik tümörler (koryokarsinom, hidatidiform mol) ile ilişkili olarak da ortaya çıkabilir. İnsidansı 1:2.000 ila 1:60.000 gebelik arasında değişir. Ayrıca, özellikle Graves hastalığı olmak üzere diğer otoimmün hastalıkları geliştirme riski de artmaktadır. Pemfigoid gestasyon genellikle daha erken başlangıçlı ve artan ciddiyetle sonraki gebeliklerde tekrarlama eğilimindedir (Snarskaya et al., 2019; AmbrosRudolph and Sticherling, 2017; Bitirgen ve ark., 2016; Can Gürkan ve Toraman, 2013; İnan Yüksel ve ark., 2011; Ambros-Rudolph, 2011; Polat ve Dönmez, 2008).

Belirtiler; Hastalık tablosu sıklıkla gebeliğin ikinci ve üçüncü trimesterinde görülmeye (ortalama 21. gebelik haftasında) başlar. Fakat vakaların $\% 25$ inde birinci trimester ve postpartum periyotta da başlayabilir. Pemfigoid gestasyon, bazen deri lezyonlarının ortaya çıkmasından önce gelebilen yoğun kaşıntı ile kendini gösterir. Başlangıçta, tipik olarak karında eritemli ürtikeryal papüller ve plaklar gelişir, karakteristik olarak umblikal bölgeyi tutar, ancak tüm cilt yüzeyine yayılabilir. Bu sözde büllöz aşamada, pemfigoid gestasyon ile gebeliğin polimorfik püskürmesi arasındaki ayrım, hem klinik hem de histopatolojik olarak neredeyse imkânsızdır. Tanı, lezyonlar büllöz pemfigoiddekilere benzeyen gergin kabarcıklara ilerlediğinde netleşir. Yüz ve mukoza zarları genellikle korunur (Snarskaya et al., 2019; AmbrosRudolph and Sticherling, 2017; Bitirgen ve ark., 2016; Can Gürkan ve Toraman, 2013; İnan Yüksel ve ark., 2011; Ambros-Rudolph, 2011; Polat ve Dönmez, 2008).

Tanı testleri: Lezyonel deriden histopatolojik bulgular hastalığın evresine ve şiddetine bağlıdır. Prebüllöz evre, lenfositler, histiyositler ve çeşitli eozinofillerden oluşan baskın olarak perivasküler inflamatuar infiltratın eşlik ettiği üst ve orta dermiste ödem ile karakterize edilirken, büllöz evre, ultra yapısal olarak konumlandırılabilen subepidermal blister oluşumunu ortaya çıkarır.

Pemfigoid gestasyonun tanısında altın standart olan perilezyonel derinin direkt immünofloresansı, dermoepidermal junction (DEJ) boyunca vakaların \%100'ünde lineer C3 
birikimi ve \%30'unda ek IgG birikimi gösterir. Uygulanan tekniğe bağlı olarak, hastanın serumunda dolaşan IgG antikorları, tuz bölünmüş cilt üzerindeki yapay yarığın çatısına bağlanarak vakaların\%30-100'ünde dolaylı immünofloresan ile tespit edilebilir. Antikor seviyeleri de modern ELISA ve immünoblot teknikleri kullanılarak izlenebilir ve hastalık aktivitesi ile iyi bir korelasyon gösterebilir (Snarskaya et al., 2019; Ambros-Rudolph and Sticherling, 2017; Bitirgen ve ark., 2016; İnan Yüksel ve ark., 2011; Ambros-Rudolph, 2011; Polat ve Dönmez, 2008).

Prognoz: Pemfigoid gestasyonun doğal seyri, gebelik sırasında alevlenmeler ve gerilemeler ile karakterizedir, gebeliğin geç dönemlerinde sık sık iyileşme ve ardından doğum sırasında alevlenmeler olur (hastaların \%75'i). Doğumdan sonra lezyonlar genellikle haftalar ila aylar içinde düzelir, ancak menstrüasyon ve hormonal kontrasepsiyonla tekrarlayabilir. Nadiren, birkaç yıl boyunca cilt lezyonlarının kalıcı olduğu şiddetli seyirler görülebilir. Fetal prognoz genellikle iyidir ancak prematüre bebek sayısında artış vardır. Anneden fetüse pasif bir antikor transferi nedeniyle, yenidoğanların yaklaşık \%10'unda günler ile haftalar arasında kendiliğinden düzelen hafif cilt lezyonları gelişebilir (Snarskaya et al., 2019; Ambros-Rudolph and Sticherling, 2017; Bitirgen ve ark., 2016; İnan Yüksel ve ark., 2011; Ambros-Rudolph, 2011; Polat ve Dönmez, 2008).

Tedavi: Tedavi, hastalığın evresine ve şiddetine bağlıdır ve kaşıntıyı kontrol etmeyi ve kabarcık oluşumunu önlemeyi amaçlar. Pemfigoid gestasyones (PG)'de bül oluşmadan önceki erken dönemde pruritusu azaltmada ılık banyolar, kompres ve emolientler yararlı olabilir. Yine bu dönemde güçlü topikal kortikosteroidler ve antihistaminikler kullanılır. Sadece hafif ön kabarcıklı pemfigoid vakalarında, oral antihistaminik içeren veya içermeyen topikal kortikosteroidler yeterli olabilir. Diğer tüm vakalar, gebelikte güvenli kabul edilen sistemik kortikosteroidler (prednizolon, genellikle $0.5 \sim 1 \mathrm{mg} / \mathrm{kg} /$ gün dozunda başlar) gerektirir. Hastalık düzeldiğinde, doz genellikle azaltılabilir, ancak doğumdaki yaygın alevlenmeyi önlemek için zamanla artırılmalıdır. Sistemik kortikosteroid tedavisine yanıt vermeyen vakalar immünoaferezden fayda görebilir. Doğumdan sonra gerekirse, immünosüpresif tedavinin tamamı uygulanabilir (Snarskaya et al., 2019; Ambros-Rudolph and Sticherling, 2017; Bitirgen ve ark., 2016; İnan Yüksel ve ark., 2011; Ambros-Rudolph, 2011; Polat ve Dönmez, 2008).

\section{Gebeliğin Polimorfik Erüpsiyonu (GPE)}

Gebeliğin polimorfik erüpsiyonu, genellikle strialarda yoğunlaşan, şiddetli kaşıntılı eritemli papül, plak ve ürtikeryal lezyonlar ile karakterize selim bir gebelik dermatozudur. 
Sıklıkla primiparlarda ve gebeliğin üçüncü trimesterinde, nadiren erken postpartum dönem de görülür ve sonraki gebeliklerde genellikle tekrarlamaz (Parlak, 2007; Matz et al.,2006; Ahmadi and Powell, 2005). Sıklığı yaklaşık 1:160 gebeliktir ve durum aşırı anne kilo alımı ve çoğul gebelikler (\%13) ile ilişkilidir (Snarskaya et al., 2019; Ambros-Rudolph and Sticherling, 2017; Bitirgen ve ark., 2016; Can Gürkan ve Toraman, 2013; İnan Yüksel ve ark., 2011; AmbrosRudolph, 2011; Polat ve Dönmez, 2008).

Etiyoloji ve patogenez: GPE'un etyolojisi tam olarak bilinmemekle birlikte, üzerinde en çok durulan görüş, abdominal duvarın aşırı gerilmesi ve bunun sonucu olarak bağdokusunda ortaya çıkan hasarın immunolojik cevabı tetiklediğidir (Polat ve Dönmez, 2008). Lezyonların sıklıkla abdominal duvardaki strialardan başlaması, çoğul gebeliği olan, gebeliği sırasında aşırı kilo alan gebelerde daha sık görülmesi bu teoriyi destekleyen bulgulardır (Rudolph et al., 2006). Ayrıca hastalığın gebeliğe özel olması ve çoğul gebeliklerde daha sık görülmesi hormonal faktörlerin rolünü düşündürmüştür.

Belirtiler: İlk gebelikte ve gebeliğin son birkaç haftasında sıklıkla başlamakla birlikte ikinci trimester ve postpartum periyotta da başlayabilir. GPE ortalama altı hafta devam eder ve PG'nin aksine sonraki gebeliklerde tekrarlamaz. Genellikle şiddetli kaşıntı, eritemli papül, plak ve ürtikeryal lezyonlar ile kendini gösteren bir tablodur. Polimorfik gebelik döküntüsü tipik olarak karın bölgesinde, stria distensae içinde başlar, şiddetli kaşıntılı ürtikeryal papüllerle birleşerek kalçalara ve proksimal uyluklara yayılır. Çoğunlukla püskürme bu bölgelerde kalır, ancak ciddi vakalarda hızla genelleşebilir. Pemfigoid gestasyonun aksine göbek bölgesinin korunması karakteristik bir bulgudur. Daha sonra morfoloji daha polimorfik hale gelir ve hastaların yarısında veziküller (1 $2 \mathrm{~mm}$ boyutunda) yaygın ürtikasyonsuz eritem, targetoid ve ekzematöz lezyonlar gelişir. Döküntü genellikle doğumdan bağımsız olarak 4 6 hafta içinde geçer (Snarskaya et al., 2019; Ambros-Rudolph and Sticherling, 2017; Bitirgen ve ark., 2016; Can Gürkan ve Toraman, 2013; İnan Yüksel ve ark., 2011; Ambros-Rudolph, 2011; Polat ve Dönmez, 2008).

Prognoz: Hastalık süresi genellikle 6 haftayı aşmaz ve spontan iyileşir (Rudolph et al., 2006). Şiddetli kaşıntının anneye verdiği sıkıntı dışında prognoz iyidir. Maternal ve fetal prognoz bozulmamıştır ve yenidoğanın kutanöz tutulumu yoktur. Lezyonlar kendi kendini sınırlar ve hastalık tekrarlamama eğilimindedir; Bunun istisnası hem erken prezentasyon hem de sonraki bir gebelikte tezahürün meydana gelebileceği çoğul gebeliklerdir (Snarskaya et al., 
2019; Ambros-Rudolph and Sticherling, 2017; Bitirgen ve ark., 2016; İnan Yüksel ve ark., 2011; Ambros-Rudolph, 2011; Polat ve Dönmez, 2008).

Tanı testleri: Histopatoloji spesifik değildir ve hastalığın evresine göre değişir. Eozinofillerle iç içe geçmiş yüzeysel ve orta dermal perivasküler lenfohistiyositik infiltratın yanı sıra, erken biyopsiler belirgin bir dermal ödem gösterirken, daha sonraki biyopsiler spongioz, hiper ve parakeratoz gibi sık epidermal değişiklikleri ortaya çıkarır. Doğrudan ve dolaylı immünofloresan incelemeleri, gebeliğin polimorfik püskürmesinde esasen olumsuzdur (Snarskaya et al., 2019; Ambros-Rudolph and Sticherling, 2017; Bitirgen ve ark., 2016; İnan Yüksel ve ark., 2011; Ambros-Rudolph, 2011; Polat ve Dönmez, 2008).

Tedavi: Antihistaminik içeren veya içermeyen topikal kortikosteroidlerle semptomatik tedavi genellikle kaşıntı ve deri lezyonlarını kontrol etmek için yeterlidir. Şiddetli jeneralize vakalarda, kısa bir sistemik kortikosteroid kürü (prednizolon, birkaç gün boyunca dozları azaltarak 40 $60 \mathrm{mg}$ / gün) gerekli olabilir ve genellikle çok etkilidir. Hafif vakalarda eğer sınırlı bir alan etkilenmişse, hafif topikal steroidli kremler kullanılabilir. Ciddi vakalarda potent topikal steroidler ve oral steroidler kullanılabilir. Oral antihistaminikler genellikle faydasızdır. (Snarskaya et al., 2019; Ambros-Rudolph and Sticherling, 2017; Bitirgen ve ark., 2016; Can Gürkan ve Toraman, 2013; İnan Yüksel ve ark., 2011; Ambros-Rudolph, 2011; Polat ve Dönmez, 2008).

\section{Gebeliğin Atopik Erüpsiyonu (GAE)}

Gebelikte atopik erüpsiyon, gebeliğin diğer dermatozları dışlandıktan sonra atopik diyatezi olan hastalarda ekzematöz veya papüler lezyonları içeren iyi huylu bir kaşıntılı gebelik bozukluğudur. Gebelikte en sık görülen dermatozdur, hastaların\%50'sini oluşturur, genellikle erken başlar, \%75'inde üçüncü trimesterden önce başlar ve atopik sonraki gebeliklerde tekrarlama eğilimindedir. Genellikle kaşıntılı gebelik dermatozlarının \%30-50'sini oluşturur (Ambros-Rudolph et al., 2006; Ambros-Rudolph, 2011).

GAE patogenezinin gebeliğe özgü immünolojik değişikliklerle tetiklendiği düşünülmektedir; atopik kişilerde deri bulgularının ilk kez ortaya çıkması, tipik olarak gebelikte T helper 2 (Th2) immün cevabının baskın hale gelmesi ile ilişkilidir. Bu nedenle, önceden var olan atopik dermatitin alevlenmesi ve atopik deri değişikliklerinin ilk tezahürü, hamilelik için tipik olan baskın bir Th2 bağışıklık tepkisi ile açıklanabilir (Snarskaya et al., 2019; AmbrosRudolph and Sticherling, 2017; Bitirgen ve ark., 2016; Can Gürkan ve Toraman, 2013; İnan Yüksel ve ark., 2011; Ambros-Rudolph, 2011; Polat ve Dönmez, 2008). 
Etyoloji ve Patogenez: Mevcut atopik dermatitin kötüleşmesinin yanı sıra, atopik kişilerde deri bulgularının ilk kez ortaya çıkması, tipik olarak gebelikte Th2 immün cevabının baskın hale gelmesi ile ilişkilidir.

Belirtileri: Atopik deri bulguları hastaların \%80'inde ilk defa ortaya çıkarken, \%20'sinde ise var olan atopik dermatitin alevlenmesiyle ortaya çıktığı bilinmektedir. Ayrıca hastaların \%20'si, tipik bir klinik tabloyla birlikte önceden var olan atopik dermatitin alevlenmesinden yoksunken, kalan\%80'i ilk kez veya uzun bir remisyondan sonra (örneğin çocukluktan beri) atopik cilt değişiklikleri yaşar. Bunlardan üçte ikisi, genellikle yüz, boyun, dekolte ve ekstremitelerin bükülme yüzeyleri gibi tipik atopik bölgeleri etkileyen yaygın ekzematöz değişiklikler (E-tipi GAE) ile mevcutken, üçte birinde papüler lezyonlar (P-tipi GAE) İkincisi, gövde ve uzuvlara yayılan küçük eritemli papülleri içerir ve çoğunlukla kollarda bulunan tipik prurigo nodülleri görülür (Snarskaya et al., 2019; Ambros-Rudolph and Sticherling, 2017; Bitirgen ve ark., 2016; Can Gürkan ve Toraman, 2013; İnan Yüksel ve ark., 2011; AmbrosRudolph, 2011; Polat ve Dönmez, 2008).

Tanı testleri: Histopatoloji spesifik değildir ve hastalığın klinik tipi ve evresine göre değişir. Doğrudan ve dolaylı immünofloresans negatiftir. Laboratuvar testleri, Serum total IgE seviyesi yüksek bulunabilir yani yüksek serum IgE düzeylerini \%20 70 ortaya çıkarabilir (Snarskaya et al., 2019; Ambros-Rudolph and Sticherling, 2017; Bitirgen ve ark., 2016; Can Gürkan ve Toraman, 2013; İnan Yüksel ve ark., 2011; Ambros-Rudolph, 2011; Polat ve Dönmez, 2008).

Prognoz: Deri lezyonları genellikle tedaviye hızlı yanıt verir ve çoğunlukla gebelik sırasında belirgin düzelme olur. Sonraki gebeliklerde tekrarlama yaygındır. Fetal prognoz etkilenmez, ancak daha sonra bebekte atopik cilt değişiklikleri geliştirme riski olabilir (Snarskaya et al., 2019; Ambros-Rudolph and Sticherling, 2017; Bitirgen ve ark., 2016; İnan Yüksel ve ark., 2011; Ambros-Rudolph, 2011; Polat ve Dönmez, 2008; Parlak, 2007).

Tedavi: Topikal kortikosteroidlerle birlikte birkaç gün süren temel tedavi, genellikle cilt lezyonlarında hızlı bir iyileşme sağlar. Şiddetli vakalarda kısa süreli sistemik kortikosteroidler ve antihistaminikler gerekebilir; fototerapi (UVB), özellikle erken gebelikte şiddetli vakalar için güvenli bir ek araçtır (Snarskaya et al., 2019; Ambros-Rudolph and Sticherling, 2017; Bitirgen ve ark., 2016; İnan Yüksel ve ark., 2011; Ambros-Rudolph, 2011; Polat ve Dönmez, 2008). 


\section{Gebelik Dermatozlarında Hemşirelik Bakımı}

Kadının yaşam kalitesini ve fetüs sağlığını olumsuz etkilemesi nedeni ile gebelik dermatozlu kadının bakımında hemşire, ayrıntılı öykü almalı, değerlendirme yapmalı ve uygun bakım planı hazırlayarak kadını izlemelidir. Bunun yanı sıra kadınların eğitimi son derece önemlidir. Dermatozlu kadınlar, hastalığın gebelik ve fetüste meydana getirebileceği olası riskler hakkında eğitilmeli, doğum sonrası kadınların bebeklerini emzirmede herhangi bir sorun olmayacağı da açıklanmalıdır. Dermatozlu gebelerde hemşirelik bakımı, gebelik boyunca anne ve fetüsün sağlığının korunması amacıyla anne ve fetüsün sürekli ve dikkatle izlenmesi ve oluşabilecek riskli durumların engellenmesini içerir (Can Gürkan ve Toraman, 2013). Gebelik dermatozlarında olumsuz sonuçlar aşağıdaki hemşirelik girişimleri ile azaltılabilir veya giderilebilir.

Sonuç olarak; gebelik dermatoz tanısı konan gebelerin fiziksel ve psikososyal gereksinimleri vardır. Tüm gebelik dermatozlarında, hastaların tedavi ve bakımında dermatolog, hepatolog, jinekolog, pediatrist ve hemşireler iş birliği içinde olmalıdır. Tanı hızla konmalı, anne ve fetüs sağlığı yakından izlenmelidir (Güleç ve Sevil 2013).

\section{KAYNAKLAR}

Ahmadi S, Powell FC. (2005). Pruritic urticarial papules and plaques of pregnancy: current status. Australas $J$ Dermatol, 46(2), 53-58.

Ambros-Rudolph C.M. Müllegger R.R. Vaughan-Jones S.A. Kerl H. Black M.M. (2006). The Specific Dermatoses of Pregnancy Revisited and Reclassified: Results of A Retrospective Two-Center Study on 505 Pregnant Patients. Journal of the American Academy of Dermatology, 54(3), 395-404.

Ambros-Rudolph C.M. (2011). Dermatoses Of Pregnanc-Clues To Diagnosis, Fetal Risk And Therapy. Annals of Dermatology, 23(3): 265-275.

Ambros-Rudolph C.M. Sticherling M. (2017). Spezifische Schwangerschaftsdermatosen [Specific Dermatoses of Pregnancy]. Der Hautarzt, 68(2): 87-94.

Bitirgen E. Köşüş A. Namlı Kalem M., Duran M., Köşüş N. (2016). Gebelikte Cilt Hastalıkları (Skin Diseases In Pregnancy). Jinekoloji-Obstetrik ve Neonatoloji Tıp Dergisi, 13(2), 79-83.

Can Gürkan Ö., Toraman B. (2013). Gebelik Dermatozları ve Hemşirelik Bakımı. Fırat Sağlık Hizmetleri Dergisi, 8(22), 19-35.

Chander R. Garg T. Kakar S. Jain A. (2011). Specific Pregnancy Dermatoses In 1430 Females From Northern India, Journal of Dermatological Case Reports, Dec 12, 5(4), 69-73.

Germain AM, Carvajal JA, Glasinovic JC, Kato C S, Williamson C. (2002). Intrahepatic Cholestasis of Pregnancy: An Intriguing Pregnancy-Specific Disorder. The Journal of the Society for Gynecologic Investigation, 9, 1014. 
Güleç D., Sevil Ü. (2013). Gebelik Intrahepatik Kolestazı Ve Hemşirelik Bakımı. Ege Üniversitesi Hemşirelik Fakültesi Dergisi, 29 (2), 95-103.

Holmes RC, Black MM. (1982). The specific dermatoses of pregnancy: a reappraisal with special emphasis on a proposed simplified clinical classification. Clinical and Experimental Dermatology, 7(1), 65-73.

Holmes R.C. Black M.M. (1983). The Specific Dermatoses of Pregnancy. Journal of the American Academy of Dermatoogyl, 8(3), 405-412.

İnan Yüksel E. Turgut Erdemir A. Turan E. Kiremitçi Ü. Gürel M.S. (2011).Gebeliğe Özgü Dermatozlar ve Tedavileri (Pregnancy Dermatoses and Treatments). Istanbul Tıp Dergisi, 12(1), 30-35.

Kroumpouzos G. (2002). Intrahepatic cholestasis of pregnancy: what's new ? European Academy of Dermatology and Venereology JEADV, 16, 316-318.

Kurien G. Badri T. (2020). Dermatoses of Pregnancy. Jun 27. In: Statpearls [Internet]. Treasure Island (FI): Statpearls Publishing; 2021 Jan-. Pmıd: 28613614.

Lammert F, Marschall HU, Glantz A, Matern S. (2000). Intrahepatic cholestasis of pregnancy: molecular pathogenesis, diagnosis and management. Journal of Hepatology, 33(6), 1012-1021.

Matz H, Orion E, Wolf R. (2006). Pruritic urticarial papules and plaques of pregnancy: polymorphic eruption of pregnancy (PUPPP). Clinical Dermatology, 24(2), 105-108.

Medenica L. Vesic S. Sretenovic-Vukicevic J. (2008). Specific Dermatoses of Pregnancy-New Classification and Differential Diagnosis. Med Pregl, 61(11-12), 586-590.

Mullally B.A, Hansen W.F. (2002). Intrahepatic cholestasis of pregnancy: review of the literature. Obstetrical \& Gynecological Survey, 57(1), 47-52.

Parlak AH. (2007). Gebeliğe Özel Dermatozlar. Türkderm, 41 (Özel sayı 1): 1- 17.

Polat P. Dönmez E.M. (2008). Gebelik Dermatozları. Türk Jinekoloji ve Obstetrik Derneği Dergisi, 5(4), $241-247$.

Powell AM, Sakuma-Oyama Y, Oyama N, Albert S, Bhogal B, Kaneko F, Nishikawa T, Black MM. (2005). Usefulness of BP180 NC16a enzyme-linked immünosorbent assay in the serodiagnosis of pemphigoid gestationis and in differentiating between pemphigoid gestationis and pruritic urticarial papules and plaques of pregnancy. Arch Dermatol, 141, 705-710.

Rudolph CM, Al-Fares S, Vaughan-Jones SA, Müllegger RR, Kerl H, Black MM. (2006). Polymorphic eruption of pregnancy: clinicopathology and potential trigger factors in 181 patients. The British Journal of Dermatology, 154(1), 54-60.

Sachdeva S. (2008). The Dermatoses of Pregnancy. Indian Journal of Dermatology, 53(3), 103-105.

Sherard GB, Atkinson SM. (2001). Focus on Primary care Pruritic dermatological conditions in pregnancy. Obstetrical \& Gynecological Survey, 56(7), 427-432.

Shornick JK. Pregnancy dermatoses. In:. Bolognia JL, Jorizzo JL, Rapini RP, Callen JP, Horn TD, Mancini AJ, eds Dermatology. 2nd ed. Vol 1. New York: Mosby, 2008; 395- 402.

Shornick J.K. (1998). Dermatoses of Pregnancy. Seminars in Cutaneous Medicine and Surgery, 17(3), $172-181$.

Snarskaya E.S. Olisova O.Y. Makatsariya A.D. Kochergin N.G. Radetskaya L. Bitsadze, V. et al. (2019). Skin Pathologies In Pregnancy. Journal of Perinatal Medicine, May 27, 47(4), 371-380. 
Vora R.V. Gupta R. Mehta M.J. Chaudhari A.H. Pilani A.P. Patel N. (2014). Pregnancy And Skin. Journal of Family Medicine and Primary Care, 3(4), 318-324. 